\title{
Inhibiting ability of benzathine penicillin $G$ towards group A Streptococcus $\beta$-hemolyticus in 21 and 28 days after a single intramuscular injection
}

\author{
Bambang Madiyono, MD, PhD; Mulyadi M Djer, MD; Sudigdo Sastroasmoro, MD, PhD; \\ Amin Subandrio, MD; Erni Erfan
}

\begin{abstract}
Background The effectiveness of a single intramuscular benzathine penicillin $G$ as a secondary prevention of acute rheumatic fever after 28 days is still controversial. The latest study showed that serum penicillin concentration was below protective level in 4 weeks after a single intramuscular injection.

Objective This study was a preliminary study to compare the inhibiting ability of benzathine penicillin $\mathrm{G}$ towards group A Streptococcus $\beta$-hemolyticus in 21 and 28 days after a single IM injection by using Mueller-Hinton broth method.

Methods The inhibiting ability was measured by the serum inhibitory concentration and serum bactericidal concentration after a single intramuscular injection of benzathine penicillin G 1.2 million units.

Results The subjects were 28 patients, with mean age of 15.5 years (SD 3.4). The numbers of male and female were equal. Mean serum inhibitory concentration in 21 days after a single injection was 926.4 (SD 3080.1) and after 28 days was 1540.9 (SD 4275.1), which was not significantly different $(\mathrm{p}=0.0662)$. Mean serum bactericidal concentration in 21 days after IM injection was 1579.6 (SD 4265.7) and in 28 days was 2417 (SD 6849.4) and it was not statistically different $(p=0.2276)$.

Conclusion This study concluded that there was no significant difference in the inhibiting ability of benzathine penicillin $G$ towards group A Streptococcus $\beta$-hemolyticus between 21 and 28 days after a single intramuscular injection [Paediatr Indones 2003;43:136-139].
\end{abstract}

Keywords: Acute rheumatic fever, benzathine penicillin, serum inhibitory concentration, serum bactericidal concentration.

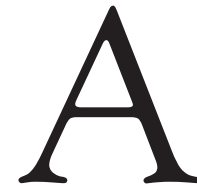

cute rheumatic fever (RF) is a leading cause of acquired heart disease among children older than 5 years up to adolescence in developing countries. It is estimated that the prevalence of rheumatic heart disease in Indonesia is around 0.3-0.8 per 100 schoolage children aged between $5-15$ years. In endemic population, approximately $0.3 \%$ suffer from $\mathrm{RF}$ whereas after a streptococcal infection, the incidence of RF could rise up to $3 \% .{ }^{1-3}$ Benzathine penicillin $\mathrm{G}$ (BPG) that had been used since the early fifties for secondary prevention of acute RF, was an important advance in controlling the disease. Stollerman et al ${ }^{4}$ found that the serum penicillin concentration reached or even exceeded the minimal inhibitory concentration after 1 month of BPG injection. The clinical practice of monthly (4 weekly) injections of BPG has been accepted and became the method of choice for secondary prevention of rheumatic fever.

From the Department of Child Health, Division of Cardiology, (BM, MMD, SS); Department of Microbiology (AS), Medical School, University of Indonesia, Cipto Mangunkusumo Hospital; Biomedical Science Post Graduate UI Student (EE).

Reprint requests to: Mulyadi M Djer, MD, Division of Cardiology, Department of Child Health, Medical School, University of Indonesia, Jakarta, Indonesia. Tel. 62-21-3907740, Fax. 62-21-3907743. 
Bambang Madiyono et al: Inhibiting ability of benzathine penicillin G towards group A Streptococcus $\beta$-hemolyticus

However, information of penicillin effectiveness in every 4-week interval still gives an interest to many scientists. Ginsburg 5 in one of his study on 6 patients, reported serum penicillin concentration at 1 month after injection was very low or even non-detectable. Another study by Lue, ${ }^{6}$ pointed out there was a significant increase in rheumatic fever recurrences in a group given BPG every 4 weeks compared to that of the 3-week group. Meanwhile, Padmavati ${ }^{7}$ reported the results of 3 -week interval injection associated with decreased number of relapse compared to those of the 4-week group. Kaplan ${ }^{8}$ concluded that serum penicillin concentration after 4 weeks was below $0.02 \mathrm{mg} /$ $\mathrm{ml}$, a concentration considered inadequate to inhibit the streptococcus. Data comparing serum inhibitory concentration (SIC) and serum bactericidal concentration (SBC) are not available up to now. This study was a preliminary study to compare SIC and SBC in patients on day 21 and 28 after getting injection.

\section{Methods}

Serum was taken from subjects who had BPG injection (Retarpen) of 1.2 million units, in week 4 according to the schedule and then in the subsequent week 3 , at our outpatient clinics of Cardiology Subdivision, Department of Child Health, Medical School, University of Indonesia/Cipto Mangunkusumo Hospital. Informed consent was taken from patients and their parents. Soon after a blood sample was taken, it was centrifuged with $5000 \mathrm{rpm}$. Serum was separated and stored in $-70^{\circ} \mathrm{C}$ temperature, to be sent later to the Department of Microbiology, Medical School, University of Indonesia/Cipto Mangunkusumo Hospital for SIC and SBC analysis.

All subjects, regardless of their age, received BPG (Retarpen) 1.2 million units. They were asked to come again on week 4 for blood sampling and then they received another BPG injection. Three weeks afterwards subjects were asked to come again for the second blood sample. There were 28 patients being analyzed for SIC and SBC in this study.

SIC and SBC analysis was done by MuellerHinton broth technique. ${ }^{9}$ Serum was diluted by $1 / 2$, $1 / 4,1 / 8,1 / 2 \mathrm{n}$ up to 15 tubes. In every tube, $20 \mathrm{ml}$ broth was added with appropriate amount of bacteria. All tubes were incubated in $37 \mathrm{oC}$ for 18-24 hours.
SIC is the lowest dilution that can visibly inhibit microbacteria, while SBC is the highest dilution (lowest concentration) that able to eliminate microbacteria.

Data were presented as mean and standard deviation or median and ranges. All data were processed using Epi-info 6.0 version. $\mathrm{P}$ value of $<0.05$ was regarded as significant.

\section{Results}

There were 28 patients aged between 10 and 23 years with median age of 15.5 years. Male and female patients were equal in number. Body weight ranged from 27 to $77 \mathrm{~kg}$, median weight was $46.4 \mathrm{~kg}$. Subjects were rheumatic fever or rheumatic heart disease patients who came regularly to cardiology outpatient clinic for secondary prevention therapy of RF and RHD.

After analysis of SIC/SBC done by comparing serum on day $21^{\text {st }}$ and $28^{\text {th }}$, decreased concentration was only found in 7 patients (25\%), while other 21 patients $(75 \%)$ maintained sufficient concentration.

SIC on day $21^{\text {st }}$ ranged from 2 to 16384 with mean concentration of 926.4 (SD 3080.1). SIC on day $28^{\text {th }}$ was 8 to 16384 with mean concentration of 1540.9 (SD 4275.1). Statistical analysis showed $\mathrm{p}$ value was 0.0662 (Table 1 ).

Table 1. Serum inhibitory concentration (SIC) on day $21^{\text {ST }}$ AND $28^{\text {TH }}$ AFTER IM INJECTION

\begin{tabular}{llllll}
\hline No & $\begin{array}{l}\text { Injection } \\
\text { Interval }\end{array}$ & Range & Mean & SD & p value \\
\hline 1 & 21 days & $2-16384$ & 926.4 & 3080.1 & 0.0662 \\
2 & 28 days & $8-16384$ & 1540.9 & 4275.1 & \\
\hline
\end{tabular}

The ratio between the highest and the lowest concentration was very high, so we made calculations by its logarithm. Mean SIC logarithm on day $21^{\text {st }}$ was 2.97 (SD 1.034). Mean serum inhibitory concentration logarithm on day $28^{\text {th }}$ was 3.19 (SD 0.932), p value was 0.0662 (Table 2 ).

TABle 2. Serum InHibitory Concentration (SIC) LOGARITHM ON DAY $21^{\text {ST }}$ AND $28^{\text {TH }}$ AFTER IM INJECTION

\begin{tabular}{lllll}
\hline No & $\begin{array}{l}\text { Injection } \\
\text { Interval }\end{array}$ & Mean & SD & p value \\
\hline 1 & 21 days & 2.97 & 1.034 & 0.0662 \\
2 & 28 days & 3.19 & 0.932 & \\
\hline
\end{tabular}


Serum bactericidal concentration value on day $21^{\text {st }}$ ranged from 2 to 16384 , mean value was 1579.6 (SD 4265), while on day $28^{\text {th }}$, it was 2 to 32768 with mean value of 2417.6 (SD 6849.4); $p$ value was 0.2276 (Table 3).

Logarithm value of serum SBC on day 21 was 3.20 (SD 1.166) whereas after day $28^{\text {th }}$ was 3.38 (SD 1.177) and $\mathrm{p}$ value was 0.2276 (Table 4).

Table 3. Serum bactericidal concentration (SBC) on DAY 21ST AND 28TH AFTER IM INJECTION

\begin{tabular}{llllll}
\hline No & $\begin{array}{l}\text { Injection } \\
\text { Interval }\end{array}$ & Ranges & Mean & SD & p value \\
\hline 1 & 21 days & $2-16384$ & 1579.6 & 4265.7 & 0.2276 \\
2 & 28 days & $2-32768$ & 2417.6 & 6849.4 & \\
\hline
\end{tabular}

Table 4. Serum bactericidal concentration (SBC) LOGARITHM ON DAY $21^{\text {ST }}$ AND $28^{\text {TH }}$ AFTER IM INJECTION

\begin{tabular}{lllll}
\hline No & $\begin{array}{l}\text { Injection } \\
\text { Interval }\end{array}$ & Mean & SD & p value \\
\hline 1 & 21 days & 3.20 & 1.166 & 0.2276 \\
2 & 28 days & 3.38 & 1.177 & \\
\hline
\end{tabular}

\section{Discussion}

This study was done to look at the controversy between 3 and 4-week interval of BPG (IM) injection in order to obtain maximal coverage of RF relapse. Previous studies had only used a small number of subjects and most of them were adult patients. ${ }^{4,5}$ Reported study on comparing SIC and SBC in both conditions was not available.

Other studies focused mainly on adequate penicillin serum concentration on day 28 after BPG injection. Stollerman et al ${ }^{4}$ stated that penicillin serum concentration reached or exceeded minimal inhibitory concentration after BPG injection at 4-week interval or more. Ginsburg ${ }^{5}$ in his study on 26 patients reported very low or even non detectable penicillin levels 4 weeks after the administration of 1.2 million units. Another study by Lue ${ }^{6}$ found an increased number of recurrences in 4-week injection group compared to the 3-week group. Kaplan ${ }^{8}$ in his study using 193 serum samples concluded that penicillin concentration was below protection level after day 28. In that study, minimum penicillin serum concentration was $0.02 \mathrm{mg} / \mathrm{ml}$.
Data obtained in our study on BPG inhibiting ability against streptococcus, using SIC and SBC, did not show differences between the 3 -week and the 4week group. Inhibitory ability of SIC and SBC in most patients (21/28) of the 4-week interval group was still sufficient and concentration reduction was found in 7 out of 28 patients. These results were supported by the fact that in our experience, recurrences on the 4week group was low and this procedure was still used as a secondary prevention in our institution. Recurrences generally developed in patients who have lack of compliance. However WHO in 196610 suggested that adults and other persons at high risk for recurrences of acute rheumatic fever should receive BPG every 3 weeks.

Based on this preliminary study we concluded that 4-week interval of 1.2 million unit BPG injection was still acceptable as secondary prophylaxis of recurrent rheumatic fever or rheumatic heart disease. Increasing the frequency to 3 -week interval was not necessary due to high cost and lack of patients' compliance, especially in developing countries. Three-week prevention interval needs to be considered only in the high risk group of recurrent rheumatic fever.

\section{Acknowledgements}

We would like to thank Biochemie that has sponsored this study

\section{References}

1. Madiyono B. Epidemiologi penyakit jantung reumatik di Indonesia. Jurnal Kardiologi Indonesia 1995;20:25-33.

2. Madiyono B. Tata laksana masalah kardiologi anak. Sari Pediatri 1994;1:147-54.

3. Wahab AS. Demam reumatik akut. In: Sastroasmoro S, Madiyono B, editors. Buku ajar kardiologi anak. Jakarta: Binarupa Aksara; 1994. p. 279-316.

4. Stollerman GH, Irvington P, Rusoff JH. Prophylaxis against group A streptococcus infection in rheumatic fever patients. JAMA 1952;150:1571-5.

5. Ginsburg CM, McCracken GH, Zweighaft TC. Serum penicillin concentration after intramuscular administration of benzathine penicillin $G$ in children. Pediatrics 1982;69: 452-4. 
Bambang Madiyono et al: Inhibiting ability of benzathine penicillin G towards group A Streptococcus $\beta$-hemolyticus

6. Lue HC, Wu MH, Hsieh KH. Rheumatic fever recurrences: controlled study of 3-week versus 4-week benzathine penicillin prevention program. J Pediatr 1986;108:299-304.

7. Padmavati S. Rheumatic fever and rheumatic heart disease in developing countries. Bulletin of the WHO 1978;56:543-50.

8. Kaplan EL, Berrios X, Speth J, Siefferman T, Guzman B, Quesny F. Pharmacokinetics of benzathine penicil- lin G: serum levels during the 28 days after intramuscular injection of 1.200 .000 units. J Pediatr 1989;115:146-50.

9. Lorian V. Antibiotics in laboratory medicine. $2^{\text {nd }}$ ed. Baltimore: William \& Wilkins; 1986. p. 466-7.

10. WHO expert committee. Prevention of rheumatic fever, WHO Technical Report Series No. 342. Geneva: World Health Organization; 1966. 